\title{
Analisis Proses Restitusi Pajak Pertambahan Nilai pada Perusahaan Jasa Konstruksi
}

\author{
Surianto $^{\varpi_{1}}$, Firda Mawarni² ${ }^{2}$ A, Sumarni $S^{3}$. \\ 1,2,3 Sekolah Tinggi Ilmu Ekonomi (STIE) Wira Bhakti Makassar \\ DOI : https://doi.org/10.37531/ecotal.v1i1.5
}

\begin{abstract}
ABSTRAK
Tujuan penelitian ini adalah untuk mengetahui dan menganalisis proses restitusi Pajak Pertambahan Nilai pada PT. Tri Star Mandiri di Makassar. Penelitian ini menggunakan metode deskriptif kuantitatif. Pengujian ini menggunakan pengumpulan data dengan cara observasi dan dokumentasi, dengan jenis data kuantitatif dan sumber data sekunder. Hasil penelitian menunjukkan bahwa PT. Tri Star Mandiri tiap tahunnya mengajukan restitusi lebih bayar pada SPT Masa PPN, karna faktur pajak yang dikeluarkan diperuntukkan bendaharawan yang memungut pajak. Dalam proses restitusi jumlah yang di ajukan tidak serta merta dikembalikan dengan $100 \%$ karna adanya ketentuan dari DJP, ataupun kesalahan dari perusahaan. Adapun hambatan yang sering dialami karna rekanan pekerjaan pihak bendarawan kurangnya memperhatikan berkas untuk lawan transaksi yang telah dipungut.
\end{abstract}

Kata Kunci:

Pajak, Pajak Pertambahan Nilai (PPN) dan Restitusi

\begin{abstract}
Abstrak : The purpose of this study was to determine and analyze the value added tax refund process at PT. Tri Star Mandiri in Makassar. This research uses descriptive quantitative method. This test uses data collection by means of observation and documentation, with quantitative data types and secondary data sources. The results showed that PT. Tri Star Mandiri annually submits overpayment refunds on periodic VAT SPT, because tax invoices are issued for treasurers who collect taxes. In the process of restitution, the amount submitted is not immediately returned $100 \%$ because of the provisions of the DGT, or the fault of the company. There are obstacles that are often experienced because the work partners of the motorists do not pay attention to the files for transaction opponents that have been collected.
\end{abstract}

Kata Kunci : Taxes, Value Added Tax (VAT) and Restitution

$\triangle$ Corresponding Author :

E-mail address: surianto@wirabhaktimakassar.ac.id (Tamamaung, Panakkukang, Makassar City, South Sulawesi)

“Received 02 December 2019, Accepted 02 January 2020, Published 17 January 2020” 
Surianto $^{\varpi_{1}}$, Firda Mawarni². A, Sumarni $\mathbf{S}^{3}$.

Analisis Proses Restitusi Pajak Pertambahan Nilai pada Perusahaan Jasa Konstruksi

DOI : https://doi.org/10.37531/ecotal.v1i1.5

\section{Pendahuluan}

Pajak merupakan salah satu sumber penerimaan negara yang sangat besar pengaruhnya terhadap peningkatan pembangunan dan kelangsungan jalannya roda pemerintahan karena jumlahnya relatif stabil. Sumber penerimaan negara yang berasal dari dalam negeri dapat dibedakan menjadi tiga, salah satunya yaitu penerimaan pajak (Komang Meli Dhanayanti \& Ketut Alit Suardana, 2017). Penerimaan negara dapat bersumber dari berbagai sektor, baik sektor internal maupun eksternal. Salah satu sumber penerimaan negara dari sektor internal adalah pajak (Ni Putu Budiadnyani, 2020). Untuk melaksanakan sistem perpajakan di Indonesia tidaklah terlalu mudah. Masyarakat di Indonesia harus mengerti pajak dan cara-cara perhitungannya, agar tidak terjadi penyimpangan dan kesalahan dalam perhitungan maupun pembayaran pajak, oleh karena itu pemerintah mengeluarkan peraturan berupa undang-undang perpajakan. Undang-undang tersebut mengatur mengenai hal-hal yang berhubungan dengan pajak, baik mengenai subjek dan objek pajak, maupun tata cara perhitungan pajak (Tirayoh, 2016:99).

Pajak adalah iuran kepada negara yang dapat dipaksakan, yang terutang oleh wajib pajak, menurut undang-undang dan peraturan undang-undang yang berlaku dengan tidak mendapat prestasi kembali secara langsung dan atau dapat dinikmati secara langsung oleh wajib pajak yang ditujukan oleh pemerintah guna membiayai pengeluaran negara, berkaitan dengan tugas negara untuk menyelenggarakan pemerintahan. Sumber penerimaan negara dari pajak telah menjadi sumber pendapatan utama dalam kehidupan suatu negara, yaitu untuk menunjang kegiatan perekonomian, menggerakan roda pemerintahan, subsidi bagi masyarakat dan pembangunan infrastruktur serta penyediaan fasilitas umum bagi masyarakat (Kadek Katon Pranata \& Ni Luh Supadmi, 2018). Menyadari peran pajak sangat penting, peningkatan penerimaan pajak menjadi tuntutan pemerintah (Muhammad Faris Naufal \& Putu Ery Setiawan, 2018).

Sistem pemungutan pajak yang berlaku di Indonesia adalah "self assessment system", dimana sistem ini memberikan kepercayaan dan tanggung jawab yang lebih besar untuk menghitung, menyetor, dan melaporkan sendiri besarnya pajak yang terutang oleh wajib pajak. Self assessment system yang diterapkan di Indonesia memberikan wewenang kepada Wajib Pajak untuk menghitung, membayar, dan melaporkan besarnya pajak terutang yang harus dibayar

Volume 1 Issue 1 (2020)

Economics and Digital Business Review

ISSN: 2774-2563 (Online) 
Surianto $^{\varpi_{1}}$, Firda Mawarni². A, Sumarni $\mathbf{S}^{3}$.

Analisis Proses Restitusi Pajak Pertambahan Nilai pada Perusahaan Jasa Konstruksi

DOI : https://doi.org/10.37531/ecotal.v1i1.5

oleh Wajib Pajak. Pemberlakuan self assessment system di Indonesia merupakan cara pemerintah untuk memberikan kepercayaan dan tanggung jawab kepada Wajib Pajak (Hapizar Triansyah \& Hapizar Triansyah, 2014). Pemerintah dalam hal ini aparat perpajakan berkewajiban melaksanakan pembinaan, penelitian, dan pengawasan terhadap pelaksanaan pemenuhan kewajiban wajib pajak. Pajak yang begitu penting sebagai sumber pembiayaan negara, dalam pemungutannya tidak lepas dari beberapa hambatan (Nabitatus Sa'adah, 2017). Kontribusi yang dilakukan oleh para wajib pajak sangat menentukan seberapa luas dan besarnya tingkat pembangunan yang nantinya dapat dilakukan pemerintah Indonesia sebagai wujud untuk meningkatkan kesejahteraan rakyat Indonesia (Putu Vio Narakusuma Ardayani \& I Ketut Jati, 2019).

Pengetahuan di bidang perpajakkan merupakan faktor penting untuk membantu wajib pajak dalam melaksanakan kewajiban perpajakkannya (Ni Kadek Metri Tresnalyani \& I Ketut Jati, 2018). Salah satu jenis pajak di Indonesia adalah Pajak Pertambahan Nilai (PPN). Pajak Pertambahan Nilai adalah pajak yang dikenakan atas komsumsi didalam negeri, yaitu yang dikenakan atas pertambahan nilai dari barang kena pajak yang dihasilkan atau yang diserahkan oleh pengusaha kena pajak yang berbentuk pabrikan, inportir, agen utama, maupun pemborong bangunan yang merupakan jasa kena pajak (I Wayan Suma, 2012).

Pajak Pertambahan Nilai (PPN) merupakan jenis pajak yang dikenakan atas setiap pembelian Barang Kena Pajak (BKP) dan jasa yang mengalami pertambahan nilai atau biasa di sebut Jasa Kena Pajak (JKP) baik di dalam wilayah Indonesia maupun dari luar daerah Pabean. Sebagaimana dalam penjelasan umum Undang-Undang No. 8 Tahun 1983 yang telah diubah terakhir dengan Undang-Undang No. 18 Tahun 2000, dinyatakan bahwa pertambahan nilai itu sendiri timbul karena dipakainya faktor-faktor produksi disetiap jalur perusahaan dalam menyiapkan, menghasilkan, menyalurkan, dan memperdagangkan barang atau pemberian pelayanan jasa kepada para konsumen.Pada dasarnya semua barang merupakan BKP, sehingga dikenakan PPN, kecuali jenis barang yang diatur dalam Undang Undang PPN. Misalnya barang hasil pertambangan atau hasil pengeboran yang diambil langsung dari sumbernya, barangbarang kebutuhan pokok yang sangat dibutuhkan oleh rakyat banyak, makanan dan minuman yang disajikan di hotel, restoran, rumah makan, warung, dan sejenisnya dan uang, emas batangan, dan surat-surat berharga. 
Surianto $^{\varpi_{1}}$, Firda Mawarni². A, Sumarni $\mathbf{S}^{3}$.

Analisis Proses Restitusi Pajak Pertambahan Nilai pada Perusahaan Jasa Konstruksi

DOI : https://doi.org/10.37531/ecotal.v1i1.5

PPN sebagai pajak objektif dapat diartikan sebagai kewajiban membayar pajak oleh konsumen yang terdiri atas orang pribadi atau badan, dan tidak berkorelasi dengan tingkat penghasilan tertentu. Siapapun yang mengonsumsi barang atau jasa yang termasuk objek PPN, akan diperlakukan sama dan wajib membayar PPN atas konsumsi barang atau jasa tersebut. Di samping sebagai pajak objektif, PPN di Indonesia termasuk dalam kategori pajak atas konsumsi.

Ditinjau dari hukum perpajakan, pajak atas konsumsi adalah pajak yang timbul akibat suatu peristiwa hukum yang menjadi beban konsumen baik secara yuridis maupun ekonomis. Maksudnya, yang dikenai pajak adalah barang-barang atau jasa yang dikonsumsi, bukan barangbarang dalam proses produksi, dan ditujukan pada konsumen akhir. PPN juga termasuk pajak tidak langsung. Sebagai pajak tidak langsung, beban pembayaran pajaknya dipikul oleh konsumen, namun penanggung jawab atas penyetoran PPN ke kas negara dibebankan kepada penjual (pajak.go.id, 2018).

Di dalam Pajak Pertambahan Nilai (PPN) terdapat istilah pajak keluaran, yaitu Pajak Pertambahan Nilai (PPN) terutang yang wajib dipungut oleh pengusaha kena pajak yang melakukan penyerahan barang kena pajak atau jasa kena pajak. Selain pajak keluaran juga terdapat istilah pajak masukan, yaitu Pajak Pertambahan Nilai (PPN) yang seharusnya sudah dibayar oleh pengusaha kena pajak karena perolehan barang kena pajak dan atau penerimaan jasa kena pajak. Apabila pajak masukan lebih besar daripada pajak keluaran maka wajib pajak akan mengalami lebih bayar dan wajib pajak mempunyai hak untuk merestitusi, karena selain mempunyai kewajiban untuk memungut pajak dari rakyat, pemerintah juga memiliki kewajiban untuk merestitusi kelebihan pajak yang telah dibayarkan oleh wajib pajak. Di masa lalu, banyak kejadian bahwa restitusi pajak menjadi modus yang kerap dipergunakan oleh wajib pajak (Badan) untuk membobol kas negara. Pola yang dilakukan bermacam-macam dari mulai meninggikan nilai pajak masukan, membeli faktur-faktur pajak keluaran ekspor perusahaan lain yang tidak terpakai,termasuk pemalsuan faktur pajak yang digunakan untuk melakukan ekspor fiktif. Kejadian seperti ini, hanya bisa berjalan langgeng, karena adanya andil dari berbagai pihak tidak hanya dari pelaku usahan namun juga termasuk oknum aparat pajak. Kejadian yang lalu ini menimbulkan stigma dan "image" yang kurang baik bagi masyarakat luas. Restitusi pajak dikonotasikan sebagai usaha pembobolan kas negara (Tirayoh, 2016:99).

Volume 1 Issue 1 (2020)

Economics and Digital Business Review

ISSN: 2774-2563 (Online) 
Surianto $^{\varpi_{1}}$, Firda Mawarni². A, Sumarni $\mathbf{S}^{3}$.

Analisis Proses Restitusi Pajak Pertambahan Nilai pada Perusahaan Jasa Konstruksi

DOI : https://doi.org/10.37531/ecotal.v1i1.5

Restitusi PPN adalah pengembalian kelebihan pembayaran PPN yang disebabkan oleh lebih besarnya nominal pajak masukan dari pada nominal pajak keluaran (Jusmani \& Rudi Qurniawan, 2016). Restitusi pajak adalah hak bagi wajib pajak (badan) bila nilai pajak masukan lebih besar daripada pajak keluaran. Proses restitusi PPN dimulai dengan diajukannya permohonan oleh WP kemudian dilanjutkan dengan pemeriksaan kemudian dilanjutkan dengan pengajuan keberatan, hingga penyelesaian keberatan (Sarah Octavia dkk, 2015). Sangatlah tidak adil apabila menyamaratakan semua wajib pajak (badan) bahwa mereka melakukan penyelewengan pajak. Bagaimana jika yang mengajukan permohonan restitusi adalah wajib pajak (badan) yang mempunyai itikad baik? Dengan adanya stigma dan image tersebut timbulah keragu-raguan di kalangan wajib pajak (badan) (khususnya perusahaan ekspor) ketika mereka akan mengajukan hak mereka (restitusi pajak).

Dalam UU Nomor 42 Tahun 2009 tentang PPN dan PPnBM pasal 9 ayat 4, diatur apabila dalam suatu masa pajak, PM yang dapat dikreditkan lebih besar daripada PK, selisihnya merupakan kelebihan pajak yang dikompensasikan ke masa pajak berikutnya. Atas kelebihan PM tersebut dapat juga diajukan permohonan pengembalian pada akhir tahun buku. Pengembalian itulah yang disebut dengan restitusi. Berkaitan dengan hal tersebut, sejumlah perusahaan mengeluhkan sulitnya proses pengajuan restitusi PPN di Ditjen Pajak. Padahal dalam pasal 17B Undang-Undang Tentang Ketentuan Umum Perpajakan (UU KUP) diatur bahwa Ditjen Pajak harus menerbitkan Surat Ketetapan Pajak Lebih Bayar (SPKLB) paling lambat 12 bulan sejak permohonan restitusi diterima secara lengkap. Jika Ditjen Pajak tidak memberikan keputusan dalam jangka waktu tersebut maka permohonan dianggap dikabulkan, dan SKPLB diterbitkan dalam waktu paling lambat 1 (satu) bulan setelah jangka waktu berakhir. Dalam rangka meningkatkan efektifitas kegiatan penegakan hukum, selain menambah dan meningkatkan kapasitas sumber daya manusia khususnya pemeriksa dan penyidik pajak, DJP juga membentuk satu direktorat baru di akhir tahun 2015, yaitu Direktorat Intelijen Perpajakan (I Gusti Putu Aditya Kusuma \& Agus Fredy Maradona, 2020).

Kemudian, dalam ayat (3) pasal tersebut pun di atur apabila Ditjen Pajak terlambat menerbitkan SKPLB maka kepada WP diberikakan imbalan bunga sebesar $2 \%$ per bulan, dihitung sejak berakhirnya jangka waktu. Jadi, sebenarnya UU KUP telah memberikan suatu kepastian hukum 
Surianto $^{\varpi_{1}}$, Firda Mawarni². A, Sumarni $\mathbf{S}^{3}$.

Analisis Proses Restitusi Pajak Pertambahan Nilai pada Perusahaan Jasa Konstruksi

DOI : https://doi.org/10.37531/ecotal.v1i1.5

bagi wajib pajak (badan) (pelaku usaha) dalam rangka mengajukan permohonan restitusi. Namun memang dalam prakteknya, sangat banyak faktor yang menghambat proses pembayaran restitusi antara lain birokrasi, interpretasi dari beberapa pasal dalam UU Perpajakan yang bisa beraneka ragam terutama yang menyangkut permintaan kelengkapan dokumen atau data perusahaan, dan lain sebagainya.

Dalam mengajukan restitusi PPN, ada beberapa hal yang harus dilakukan oleh wajib pajak mengingat hal tersebut terkait dengan kas negara. Ada tata cara pengajuan restitusi yang harus dipatuhi oleh WP. Dimulai dari pengajuan permohonan restitusi, kelengkapan dokumen untuk permohonan restitusi, dan proses penelitian atau pemeriksaan oleh Direktorat Jenderal (Dirjen) Pajak dalam permohonan restitusi. Permohonan pengembalian kelebihan pajak dapat diproses melalui penelitian atau pemeriksaan. Penelitian dilakukan terhadap permohonan pengembalian kelebihan pajak yang diajukan oleh Pengusaha Kena Pajak (PKP) kriteria tertentu, PKP yang memenuhi persyaratan sebagaimana dimaksud dalam Pasal 17D Undang-Undang Nomor 16 Tahun 2009 tentang Ketentuan Umum dan Tata Cara Perpajakan (KUP); atau PKP berisiko rendah. Selain PKP tersebut, atas permohonan pengembalian kelebihan pajaknya dilakukan pemeriksaan.

PT Tri Star Mandiri Makassar merupakan suatu perusahaan yang bergerak di bidang jasa konstruksi.Banyak perusahaan-perusahaan besar yang menggunakan jasa perusahaan untuk memperbaiki atau membangun Gedung baru baik pihak swasta maupun instansi pemerintah. Contoh kasus di dalam perusahaan PT. Tri Star Mandiri Makassar melakukan pengajuan permohonan restitusi atas anggaran dana PPN pembelian material pada proyek pemerintah yang telah dikeluarkan terlebih dulu menggunakan dana operasional perusahaan, dimana yang seharus pihak pemerintahlah yang harus memungut segala jenis pajak dalam suatu proyek pekerjaan, seperti di tahun 2018 memiliki banyak penyelesaian pekerjaan tahun kontrak 2017 dan pekerjaan kontrak baru di tahun 2018 serta memiliki pembelian material sampai dengan Desember 2018 sebesar nilai DPP Rp. 28.002.794.120,- dengan nilai PPN Rp. 2.800.279.412,akan tetapi di masa Juli dan November 2018 memiliki penyelesaian pekerjaan dari instansi swasta yang dimana rekanan tidak memungut pajak sesuai dengan ketentuan. Jadi pihak PT. Tri Star Mandiri yang dibebani pajak seutuhnya, sehingga nilai dari pekerjaan tersebut dapat mengurangi nilai PPN masukan. Sehingga PPN masukan PT. Tri Star Mandiri 31 Desember 2018

Volume 1 Issue 1 (2020)

Economics and Digital Business Review

ISSN: 2774-2563 (Online) 
Surianto $^{\varpi_{1}}$, Firda Mawarni². A, Sumarni $\mathbf{S}^{3}$.

Analisis Proses Restitusi Pajak Pertambahan Nilai pada Perusahaan Jasa Konstruksi

DOI : https://doi.org/10.37531/ecotal.v1i1.5

senilai Rp. 2.725.066.498,-, jadi dalam laporan SPT PPN masa Desember 2018 PT. Tri Star Mandiri memilih untuk dikembalikan(restitusi) senilai Rp. 2.725.066.498,-.

Aspek perpajakan untuk bidang usaha jasa konstruksi memiliki ciri kekhususan karena sifatnya yang berbeda dengan bidang usaha lainnya. Dilihat dari sisi siklus operasinya yang memiliki waktu lebih dari satu tahun sehingga pendapatan dan bebannya pun dihitung secara khusus. Jasa konstruksi adalah layanan jasa konsultasi perencanaan pekerjaan konstruksi, layanan jasa pelaksanaan pekerjaan konstruksi, dan layanan jasa konsultasi pengawasan pekerjaan konstruksi. Bidang usaha jasa konstruksi tersebut mencakup pekerjaan arsitektural, sipil, mekanikal, elektrikal dan atau tata lingkungan, masing masing beserta kelengkapannya.

\section{Kajian Literatur}

\subsection{Pengertian Pajak}

Pajak adalah iuran rakyat kepada kas negara berdasarkan undang-undang (yang dapat dipaksakan) dengan tidak mendapat jasa timbal balik (kontraprestasi) yang langsung dapat ditunjukkan dan yang digunakan untuk membayar pengeluaran umum (Resmi, 2019:1). Undang-Undang Pajak (2013:3) Pajak adalah kontribusi wajib kepada negara yang terutang oleh orang pribadi atau badan yang bersifat memaksa berdasarkan undang-undang, dengan tidak mendapatkan imbalan secara langsung dan digunakan untuk keperluan negara bagi sebesarbesarnya kemakmuran rakyat. Pengertian pajak dapat disimpulkan bahwa (1) pajak dipungut berdasarkan atau dengan kekuatan undang-undang serta aturan pelaksanaannya, (2) dalam pembayaran pajak tidak ditunjukan adanya kontraprestasi individual oleh pemerintah, (3) pajak diperuntukan bagi pengeluaran-pengeluaran pemerintah.

a. Fungsi Pajak

(Resmi. 2019:3) terdapat dua fungsi pajak, yaitu fungsi budgetair (sumber keuangan negara) dan fungsi regulerend (pengatur).

1) Fungsi Budgetair Pajak mempunyai fungsi budgetair, artinya pajak merupakan salah satu sumber penerimaan pemerintah untuk membiayai pengeluaran baik rutin maupun pembangunan.

2) Fungsi Regulerend Pajak mempunyai fungsi pengatur, artinya pajak sebagai alat untuk mengatur atau melaksanakan kebijakan pemerintah dalam sosial dan ekonomi, serta mencapai tujuan-tunjuan tertentu diluar bidang keuangan. 
Surianto $^{\varpi_{1}}$, Firda Mawarni². A, Sumarni $\mathbf{S}^{3}$.

Analisis Proses Restitusi Pajak Pertambahan Nilai pada Perusahaan Jasa Konstruksi

DOI : https://doi.org/10.37531/ecotal.v1i1.5

b. Pengelompokan Pajak

(Mardiasmo, 2011:5) pajak dikelompokan ke dalam tiga golongan, yaitu:

1) Menurut Golongannya

a) Pajak Langsung, yaitu pajak yang harus dipikul sendiri oleh Wajib Pajak dan tidak dapat dibebankan atau dilimpahkan kepada orang lain. Contoh : Pajak Penghasilan

b) Pajak Tidak Langsung, yaitu pajak yang pada akhirnya dapat dibebankan atau dilimpahkan kepada orang lain. Contoh : Pajak Pertambahan Nilai

2) Menurut Sifatnya

a) Pajak Subjektif, yaitu pajak yang berpangkal atau berdasarkan pada subjeknya, dalam arti memperhatikan keadaan diri Wajib Pajak. Contoh : Pajak Penghasilan

b) Pajak Objektif, yaitu pajak yang berpangkal pada objeknya, tanpa memperhatikan keadaan diri Wajib Pajak. Contoh : Pajak Pertambahan Nilai dan Pajak Penjualan atas Barang Mewah.

3) Menurut Lembaga Pemungutnya

a) Pajak Pusat, yaitu pajak yang dipungut oleh pemerintah pusat dan digunakan untuk membiayai rumah tangga negara. Contoh : Pajak Penghasilan, Pajak Pertambahan Nilai dan Pajak Penjualan atas Barang Mewah, dan Bea Materai.

b) Pajak Daerah, yaitu pajak yang dipungut oleh pemerintah daerah dan digunakan untuk membiayai rumah tangga daerah.

d. Pengakuan Pendapatan Konstruksi Menurut PSAK No. 34

Standar Akuntansi Keuangan secara khusus mengatur tentang pengakuan pendapatan dan biaya kontrak dengan menerbitkan sebuah penyataan PSAK No. 34 tentang Akuntansi Kontrak Konstruksi. Tujuan PSAK No. 34 adalah untuk menggambarkan perlakuan akuntansi pendapatan dan biaya yang berhubungan dengan kontrak konstruksi. Oleh karena sifat dari aktivitas yang dilakukan pada kontrak konstruksi, tanggal saat aktivitas pada kontrak mulai dilakukan dan tanggal saat aktivitas tersebut diselesaikan biasanya jatuh pada periode akuntansi yang berlainan. Oleh karena itu, persoalan utama dari akuntansi kontrak konstruksi adalah alokasi pendapatan kontrak dan biaya kontrak pada periode dimana pekerjaan konstruksi tersebut dilaksanakan.

Rangkuti (2008) dalam Smith and Skousen, ada 2 metode dalam pengakuan pendapatan jasa konstruksi, yaitu :

a. Metode Kontrak Selesai

Volume 1 Issue 1 (2020)

Economics and Digital Business Review

ISSN: 2774-2563 (Online) 
Surianto $^{\varpi_{1}}$, Firda Mawarni². A, Sumarni $\mathbf{S}^{3}$.

Analisis Proses Restitusi Pajak Pertambahan Nilai pada Perusahaan Jasa Konstruksi

DOI : https://doi.org/10.37531/ecotal.v1i1.5

Metode kontrak selesai biasanya digunakan perusahaan yang mempunyai kontrak jangka pendek atau proyek yang memiliki resiko tidak dapat diestimasi secara andal. Pada metode ini, laba dilaporkan pada periode sewaktu proyek selesai.

b. Metode Persentase Penyelesaian

Metode pengakuan pendapatan persentase penyelesaian adalah metode pengakuan yang biasanya digunakan oleh perusahaan yang memiliki kontrak jangka panjang, dimana jangka waktunya lebih dari satu periode akuntansi. Metode ini mencerminkan prestasi kerja masa berjalan atas penyelesaian kontrak lebih dari satu periode akuntansi.

Metode persentase penyelesaian dalam pengakuan pendapatan kontrak akan memerlukan kondisi-kondisi yang harus dipenuhi sebagai berikut :

a. Total pendapatan kontrak harus dapat diukur secara andal;

b. Besar kemungkinan manfaat ekonomi yang berhubungan dengan kontrak tersebut akan tertagih dan mengalir ke perusahaan;

c. Baik biaya kontrak untuk menyelesaikan kontrak maupun tahap penyelesaian kontrak pada tanggal neraca dapat diukur secara andal;

d. Biaya kontrak yang dapat diatribusikan ke kontrak dapat diidentifikasi secara jelas sehingga biaya kontrak actual dapat dibandingkan dengan estimasi sebelumnya.

e. Pajak Pertambahan Nilai (PPN)

Pajak Pertambahan Nilai adalah pajak atas konsumsi barang dan jasa di daerah pabean yang dikenakan secara bertingkat di setiap jalur produksi dan distribusi (Wahono, 2012:264). Pajak Pertambahan Nilai adalah Pajak tidak Langsung yang dikenakan pada setiap pertambahaan nilai atau transaksi penyerahan barang dan atau jasa kena pajak dalam pendistribusiannya dari produsen dan konsumen. Disebut pajak tidak langsung karena tidak langsung dibebankan kepada penanggung pajak (konsumen) tetapi melalui mekanisme pemungutan pajak dan disetor oleh pihak lain (penjual). Transaksi penyerahannya bisa dalam bentuk jual-beli, pemanfaatan jasa, dan sewa-menyewa, (arjono, 2017:59).

Pajak Pertambahan Nilai adalah pajak yang dikenakan atas komsumsi didalam negeri, yaitu yang dikenakan atas pertambahan nilai dari barang kena pajak yang dihasilkan atau yang diserahkan oleh pengusaha kena pajak yang berbentuk pabrikan, inportir, agen utama, maupun pemborong bangunan yang merupakan jasa kena pajak. Pengertian PPN ditinjau dari sudut ilmu hukum yaitu suatu jenis pajak yang menempatkan kedudukan pemikul beban pajak dengan kedudukan

Volume 1 Issue 1 (2020)

Economics and Digital Business Review

ISSN: 2774-2563 (Online) 
Surianto $^{\varpi_{1}}$, Firda Mawarni². A, Sumarni $\mathbf{S}^{3}$.

Analisis Proses Restitusi Pajak Pertambahan Nilai pada Perusahaan Jasa Konstruksi

DOI : https://doi.org/10.37531/ecotal.v1i1.5

penanggung jawab pembayaran pajak ke kas negara pada pihak-pihak yang berbeda. Hal ini dimaksudkan untuk melindungi pembeli atau penerima jasa dari tindakan sewenang - wenang negara (pemerintah). Apabila penjual atau pengusaha jasa tidak memungut PPN dari pembeli atau penerima jasa, sepenuhnya menjadi tanggung jawab penjual atau pengusaha jasa, bukan tanggung jawab pembeli atau penerima jasa.

Negara (pemerintah) tidak dapat meminta pertanggungjawaban dari pembeli atau penerima jasa. Demikian pula apabila pembeli atau penerima jasa sudah membayar PPN kepada penjual atau pengusaha jasa, ternyata oleh penjual atau pengusaha jasa (PPN tersebut) tidak pernah dilaporkan kepada negara (pemerintah), sepenuhnya menjadi tanggung jawab penjual atau pengusaha jasa. Apabila pembeli atau penerima jasa sudah membayar PPN kepada penjual atau pengusaha jasa pada dasarnya sama halnya dengan pembeli atau penerima jasa sudah membayar PPN tersebut ke kas negara. Pajak Pertambahan Nilai yang dikenakan dalam perusahaan jasa konstruksi adalah Pajak Pertambahan Nilai yang dikenakan atas pembelian bahan material yang digunakan dalam proses produksi perusahaan, Pajak Pertambahan Nilai yang diperoleh dari pembelian Barang Kena Pajak ini disebut Pajak Masukan serta Pajak Pertambahan Nilai atas penyerahan jasa konstruksi sebagai penyerahan Jasa Kena Pajak dan memungut Pajak Keluaran. Pajak Masukan yang telah dipungut dapat dikreditkan dengan Pajak Keluaran pada masa pajak yang sama tetapi jika belum dapat dikreditkan dengan Pajak Keluaran pada masa yang sama maka dapat dikreditkan selambat-lambatnya 3 (tiga) bulan setelah berakhirnya masa pajak yang bersangkutan.

Bukti pungutan pajak atas penyerahan Jasa Kena Pajak berupa faktur pajak. Saat pembuatan faktur pajak menurut PER - 24/PJ/2012 faktur pajak harus dibuat pada: (a) Saat penyerahan Barang Kena Pajak dan/atau Jasa Kena Pajak; (b) Saat penerimaan pembayaran dalam hal penerimaan pembayaran terjadi sebelum penyerahan Barang Kena Pajak dan/atau sebelum penyerahan Jasa Kena Pajak; (c) Saat penerimaan pembayaran termin dalam hal penyerahan sebagian tahap pekerjaan; (d) Saat PKP rekanan menyampaikan tagihan kepada Bendahara Pemerintah sebagai Pemungut Pajak Pertambahan Nilai; atau (e) Saat lain yang diatur dengan atau berdasarkan Peraturan Menteri Keuangan. Jenis usaha jasa konstruksi merupakan objek Pajak Pertambahan Nilai. Dalam hal ini apabila perusahaan melakukan penyerahan Barang Kena

Volume 1 Issue 1 (2020)

Economics and Digital Business Review

ISSN: 2774-2563 (Online) 
Surianto $^{\varpi_{1}}$, Firda Mawarni². A, Sumarni $\mathbf{S}^{3}$.

Analisis Proses Restitusi Pajak Pertambahan Nilai pada Perusahaan Jasa Konstruksi

DOI : https://doi.org/10.37531/ecotal.v1i1.5

Pajak dan atau Jasa Kena Pajak akan dikenakan PPN. Berdasarkan KMK563/KMK.03/2003 bahwa bendaharawan pemerintah baik pusat maupun daerah adalah pemungut PPN.

Dalam hal pembuatan Faktur Pajak mengacu pada PER - 24/PJ/2012 dimana faktur pajak harus dibuat pada saat PKP rekanan menyampaikan tagihan kepada Bendaharawan Pemerintah sebagai Pemungut Pajak Pertambahan Nilai. Sedangkan bukti bahwa Bendaharawan telah memungut PPN atas jasa konstruksi adalah berupa : (a) Faktur Pajak ; dan (b) Surat Setoran Pajak (SSP) PPN

Pemungutan PPN dilakukan dengan cara sebagai berikut:

a. Pengusaha Kena Pajak Rekanan (PKP Rekanan) menerbitkan Faktur Pajak dan SSP pada saat menyampaikan tagihan kepada Bendaharawan, baik untuk sebagian maupun seluruh pembayaran. Dalam hal pembayaran diterima sebelum penagihan, atau sebelum penyerahan Barang Kena Pajak, maka Faktur Pajak wajib diterbitkan pada saat pembayaran diterima.

b. Faktur Pajak adalah bukti pungutan pajak yang dibuat oleh PKP yang melakukan penyerahan BKP atau penyerahan JKP atau bukti pungutan pajak karena impor BKP yang digunakan oleh DitJen Bea Cukai. Terkait dengan penyerahan BKP atau JKP tersebut, peruntukan faktur pajak bagi PKP penjual digunakan sebagai pajak keluaran atas pemungutan PPN kepada PKP pembeli, sedangkan bagi PKP pembeli digunakan sebagai pajak masukan. Faktur pajak keluaran atau faktur pajak masukan tersebut harus disetor dan dilaporkan.

\section{Metode Penelitian}

Jenis data dalam penelitian ini adalah kuantitatif yaitu jenis data yang dapat diukur (measurable) atau dihitung secara langsung sebagai variabel angka atau bilangan. Variabel dalam ilmu statistika adalah atribut, karakteristik, atau pengukuran yang mendeskripsikan suatu kasus atau objek penelitian. Metode analisis dalam penelitian ini adalah metode deskriptif kuantitatif yaitu menjelaskan dan memberikan gambaran tentang proses restitusi Pajak Pertambahan Nilai pada PT. Tristar Mandiri di Makassar.

\section{Hasil dan Pembahasan}

\subsection{Pajak Pertambahan Nilai (PPN) pada PT. Tri Star Mandiri}

Dengan mengetahui pajak masukan dan pajak keluaran PT. Tri Star Mandiri, maka dapat diketahui berapa besaran pajak Lebih Bayar ataupun pajak Kurang Bayar, jika terjadi pajak 
Surianto $^{\varpi_{1}}$, Firda Mawarni². A, Sumarni $\mathbf{S}^{3}$.

Analisis Proses Restitusi Pajak Pertambahan Nilai pada Perusahaan Jasa Konstruksi

DOI : https://doi.org/10.37531/ecotal.v1i1.5

masukan lebih besar dari pajak keluaran artinya terjadi lebih bayar, sehingga Pengusaha Kena Pajak dapat memilih untuk meminta restitusi atau kompensasi atas kelebihan pembayaran pajak tersebut, akan tetapi PT. Tri Star Mandiri Makassar yang bergerak di bidang jasa konstruksi dimana rekanan pekerjaan rata-rata bersama instansi pemerintahan yang semua mengenai perpajakan atas pekerjaan tersebut dipungut oleh pemberi kerja (pemerintah).

\subsection{Restitusi pada PT. Tri Star Mandiri Tahun 2017 - 2019}

Untuk mengetahui berapa besarnya kelebihan pembayaran pajak selama tahun 2017, 2018 dan 2019 dapat dilihat pada tabel, yang dapat diuraikan sebagai berikut:

a. PPN pada tahun 2017

Tabel 1. Resume PPN 2017 PT. Tri Star Mandiri Makassar

\begin{tabular}{|c|c|c|c|c|c|c|}
\hline \multirow[t]{2}{*}{ Masa } & \multicolumn{2}{|c|}{ Masukan } & \multicolumn{2}{|c|}{ Omzet Keluaran Swasta } & \multirow{2}{*}{$\begin{array}{c}\text { Omzet Keluaran } \\
\text { yang } \\
\text { dipungut(PPN) }\end{array}$} & \multirow{2}{*}{$\begin{array}{c}\text { (Lebih)/ } \\
\text { Kurang }\end{array}$} \\
\hline & $D P P$ & $P P N M$ & Bruto & $P P N K$ & & \\
\hline Januari & 2.051 .220 .561 & 205.122 .056 & - & - & - & -205.122 .056 \\
\hline Februari & 1.435 .572 .772 & 143.557 .277 & - & - & - & -348.679 .333 \\
\hline Maret & 1.375 .918 .159 & 137.591 .816 & - & - & 26.577 .789 & -486.271 .149 \\
\hline April & 694.340 .638 & 69.434 .064 & - & - & 887.268 .382 & -555.705 .213 \\
\hline Mey & 597.379 .393 & 59.737 .939 & - & - & 987.384 .923 & -615.443 .152 \\
\hline Juni & 636.172 .716 & 63.617 .272 & - & - & 366.563 .831 & -679.060 .424 \\
\hline Juli & 4.394 .895 .598 & 439.489 .560 & - & - & 1.058 .155 .505 & -1.118 .549 .984 \\
\hline Agustus & 3.632 .983 .555 & 363.298 .356 & 839.735 .600 & 76.339 .600 & 201.813 .644 & -1.405 .508 .739 \\
\hline September & 5.557 .139 .246 & 555.713 .925 & - & - & 779.425 .729 & -1.961 .222 .664 \\
\hline Oktober & 4.556 .151 .236 & 455.615 .124 & 1.178 .988 .782 & 107.180 .798 & 1.961 .544 .757 & -2.309 .656 .989 \\
\hline Nopember & 2.537 .520 .241 & 253.752 .024 & - & - & - & -2.563 .409 .013 \\
\hline Desember & 1.717 .280 .175 & 171.728 .018 & 2.179 .953 .618 & 198.177 .602 & 1.848 .031 .556 & -2.536 .959 .429 \\
\hline Total & 29.186 .574 .290 & 2.918 .657 .429 & 4.198 .678 .000 & 381.698 .000 & 8.116 .766 .116 & \\
\hline
\end{tabular}

Berdasarkan tabel diatas dapat diketahui bahwa pada tahun 2017 data omset dan data pembelian material tersebut, dapat diterangkan bahwa pada tahun 2017 memiliki pembelian material dengan total PPN Rp. 2.918.657.429,- penyelesaian tahapan termin atau omset yang telah selesai dan cair mulai dari masa Januari sampai dengan Desember 2017 sebesar Rp. 8.498.464.116,- yang dimana terbagi antara Pekerjaan swasta Rp. 381.698.000,- dan instansi pemerintah (dipungut) Rp. 8.116.766.116,- dengan nilai yang telah tercantum pada table di atas 
Surianto $^{\varpi_{1}}$, Firda Mawarni². A, Sumarni $\mathbf{S}^{3}$.

Analisis Proses Restitusi Pajak Pertambahan Nilai pada Perusahaan Jasa Konstruksi

DOI : https://doi.org/10.37531/ecotal.v1i1.5

telah dapat diketahui nilai Lebih Bayar PPN tahun 2017 yaitu (Pembelian Material Rp. 2.918.657.429-

Pencairan pekerjaan termin swasta Rp. 381.698.000,- = Rp. 2.536.959.429,-), jadi PT. Tri Star Mandiri memilih untuk merestitusikan nilai lebih bayar di tahun 2017 sebesar (Rp. 2.536.959.429,- )

b. PPN pada tahun 2018

Tabel 2. Resume PPN 2018 PT. Tri Star Mandiri Makassar

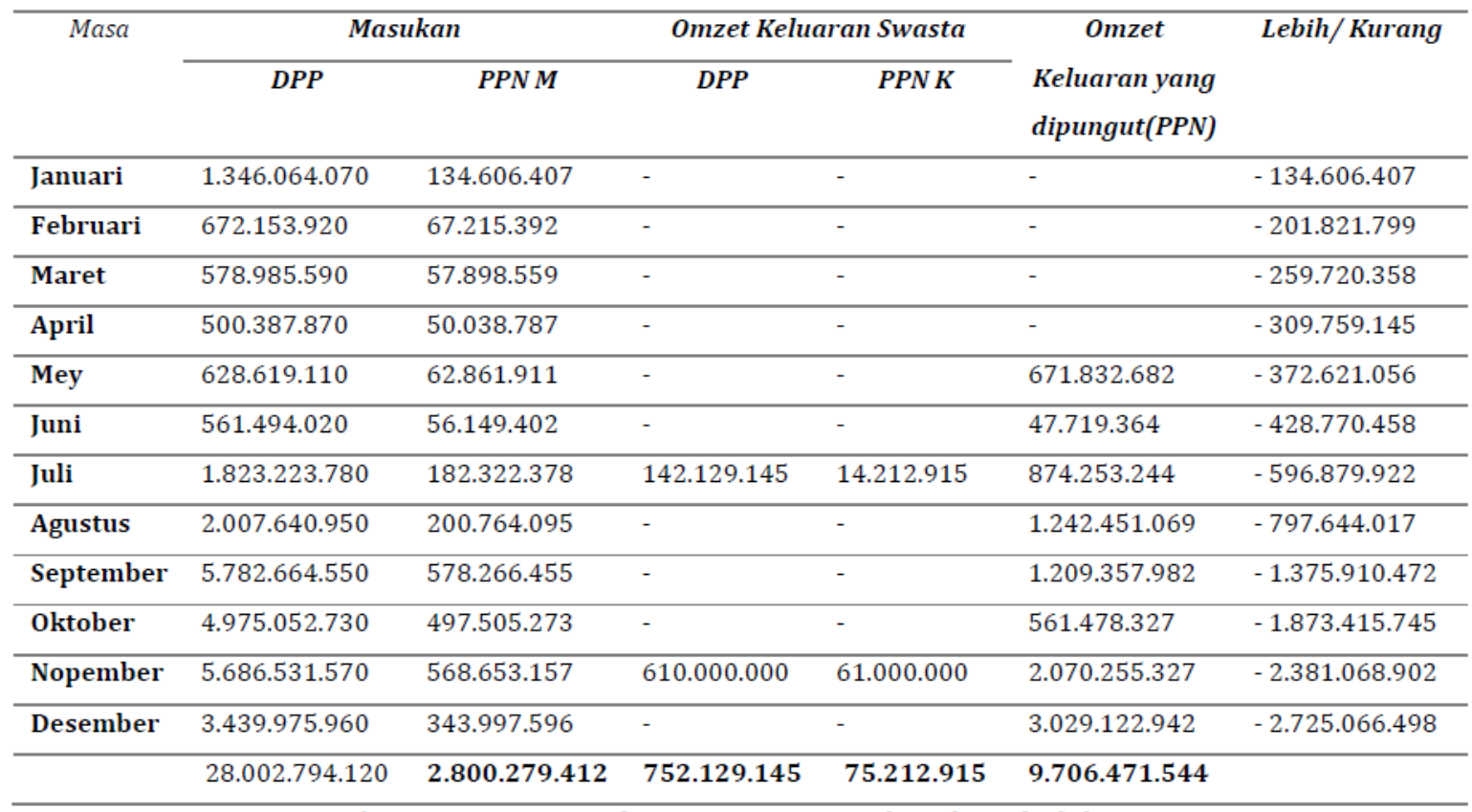

Sumber : Laporan Pajak PT. Tri Star Mandiri, data diolah 2020

Berdasarkan tabel di atas dapat diketahui bahwa pada tahun 2018 data omset dan data pembelian material tersebut, dapat diterangkan bahwa pada tahun 2018 memiliki pembelian material dengan total PPN Rp. 2.800.279.412,- penyelesaian tahapan termin atau omset yang telah selesai dan cair mulai dari masa Januari sampai dengan Desember 2018 sebesar Rp. 9.781.684.459,- yang dimana terbagi antara pekerjaan swasta Rp. 75.212.915,- dan instansi pemerintah (dipungut) Rp. 9.706.471.544,- dengan nilai yang telah tercantum pada tabel di atas telah dapat diketahui nilai Lebih Bayar PPN tahun 2018 yaitu (Pembelian Material Rp. 2.800.279.412,- - Omset pekerjaan swasta Rp. 75.212.915,- = Rp. 2.725.066.498,), jadi PT. Tri Star Mandiri memiliki Lebih Bayar Pajak PPN tahun 2018 sebesar (Rp. 2.725.066.498,-) akan 
Surianto $^{\varpi_{1}}$, Firda Mawarni². A, Sumarni $\mathbf{S}^{3}$.

Analisis Proses Restitusi Pajak Pertambahan Nilai pada Perusahaan Jasa Konstruksi

DOI : https://doi.org/10.37531/ecotal.v1i1.5

tetapi untuk tahun 2018 PT. Tri Star Mandiri memilih untuk mengkompensasikan Kelebihan Bayar Pajak tersebut ke masa berikutnya yaitu masa Januari 2019

c. PPN pada tahun 2019

Tabel 3. Resume PPN 2019 PT. Tri Star Mandiri Makassar

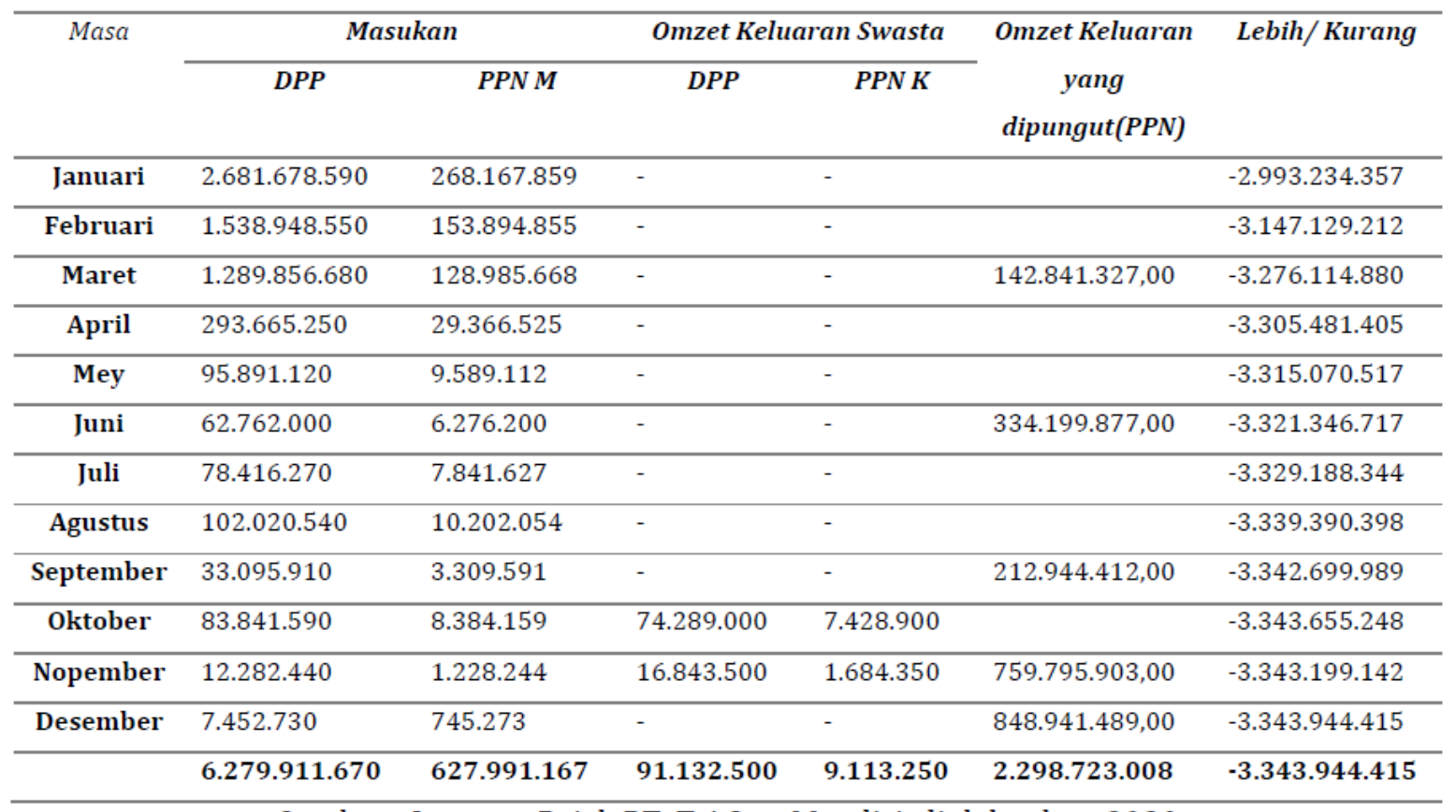

Sumber : Laporan Pajak PT. Tri Star Mandiri, diolah tahun 2020

Berdasarkan tabel di atas dapat diketahui bahwa pada tahun 2019 data omset dan data pembelian material tersebut, dapat diterangkan bahwa pada tahun 2019 memiliki pembelian material (Pajak Masukan) dengan total PPN Rp. 627.991.167,- penyelesaian tahapan termin atau omset yang telah selesai dan cair mulai dari masa Januari sampai dengan Desember 2019 (Pajak Keluaran) sebesar Rp. 2.307.836.258,- yang dimana terbagi antara Pekerjaan swasta Rp. 9.113.250,- dan instansi pemerintah (dipungut) Rp. 2.298.723.008,-. Akan tetapi kelebihan bayar PPN pada masa Desember 2018 dikompensasikan ke masa Januari 2019 senilai (Rp. 2.725.066.498,-) di jadikan saldo awal lebih bayar masa Januari 2019. Dapat di ketahui Lebih Bayar PT. Tri Star Mandiri pada Tahun 2019 yaitu (Kompensasi Tahun 2019 (Rp. 2.725.066.498,-) + Pembelian Material(PM) Rp. 627.991.167,- - Omset pekerjaan swasta(PK) Rp. 9.113.250,- = Rp. 3.343.944.415,--). Jadi PT. Tri Star Mandiri memiliki Lebih Bayar Pajak PPN pada Tahun 2019 sebesar (Rp. 3.343.944.415,-)dan PT. Tri Star Mandiri memilih untuk memilih untuk merestitusikan atas lebih bayar tersebut. 
Surianto $^{\varpi_{1}}$, Firda Mawarni². A, Sumarni $\mathbf{S}^{3}$.

Analisis Proses Restitusi Pajak Pertambahan Nilai pada Perusahaan Jasa Konstruksi

DOI : https://doi.org/10.37531/ecotal.v1i1.5

\section{Pembahasan}

\section{Pajak Pertambahan Nilai di PT. Tri Star Mandiri}

PT. Tri Star Mandiri bergerak dalam bidang jasa konstruksi di mana perusahaan tersebut mendapatkan proyek pekerjaan dengan mengikuti tender dan melalui rekanan dalam artian antar perushaan swasta. Proyek pekerjaan PT. Tri Star Mandiri banyak memenangkan tender dan melakukan perkerjaan pemerintah yang artinya lawan transaksi PT. Tri Star Mandiri yaitu bendaharawan, dimana segala jenis perpajakan pihak bendaharalah yang memungut pajak dalam proyek pekerjaan, dalam hal ini jika ada tahap pekerjaan yang telah dituntaskan maka PT. Tri Star Mandiri menerbitkan Faktur Pajak Keluaran sesuai dengan ketentuan perpajakan, dimana ada kode transaksi di nomor seri faktur pajak keluaran untuk lawan transaksi. Adapun kode transaksi faktur pajak tersebut 3 di antaranya yaitu :

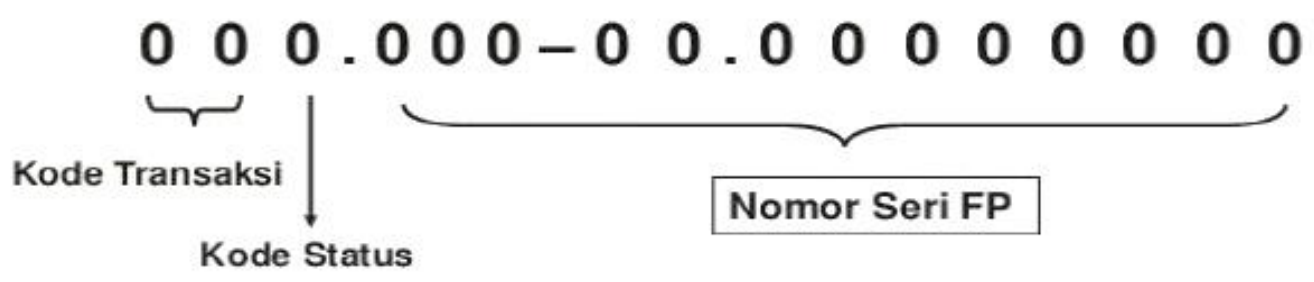

01 = penyerahan Barang Kena Pajak (BKP) dan/atau Jasa Kena Pajak (JKP) yang PPN-nya terutang dan dipungut oleh PKP penjual yang melakukan penyerahan BKP dan/atau JKP.

02 = penyerahan BKP dan/atau JKP kepada Pemungut PPN bendahara pemerintah yang PPNnya dipungut oleh pemungut PPN bendahara pemerintah.

03 =Kode ini digunakan untuk penyerahan BKP dan/atau JKP kepada Pemungut PPN lainnya (selain bendahara pemerintah) yang PPN-nya dipungut oleh pemungut PPN lainnya (selain bendahara pemerintah).Dengan begitu kode untuk lawan transaksi bendaharawan dan BUMN menggunakan kode 020 .

a. PPN Tahun 2017

Dapat dilihat pada tabel 2 resume PPN 2017 mulai dari masa Maret 2017 PT. Tri Star Mandiri telah menyelesaikan beberapa tahapan pekerjaan di masa tersebut dan telah menerbitkan Faktur Pajak Keluaran dengan menggunakan kode 020 yang artinya dipungut, jadi dalam hal tersebut semua pajak masukan dikreditkan tanpa di kurangi dengan faktur pajak keluaran yang 
Surianto $^{\varpi_{1}}$, Firda Mawarni². A, Sumarni $\mathbf{S}^{3}$.

Analisis Proses Restitusi Pajak Pertambahan Nilai pada Perusahaan Jasa Konstruksi

DOI : https://doi.org/10.37531/ecotal.v1i1.5

telah diterbitkan karna PPN dari Faktur Pajak tersebut telah dipungut oleh lawan transaksi, maka dari itu Pajak Masukan menjadi nilai Status Lebih Bayar PPN PT. Tri Star Mandiri yang terus meningkat tiap masanya karna Setiap masanya lebih bayar tersebut dikompensasikan ke masa berikutnya, akan tetapi di masa Agustus ada penyelesaian tahap pekerjaan rekanan swastasenilai Rp. 76.339.600,-di masa Oktober di terbitkan Faktur Pajak Keluaran swasta yang tidak di pungut senilai Rp. 107.180.798,- dan di masa Desember juga di terbitkan Faktur Pajak Keluaran swasta senilai Rp. 198.177.602,- maka nilai tersebut menjadi nilai pengurang Pajak Masukan. Jadi dari Januari sampai dengan Desember 2017 total nilai Pajak Masukan yang telah di kreditkan senilai Rp. 2.918.657.429,- dan di kurang Rp. 381.698.000,- karna telah diterbitkan Faktur Pajak Keluaran untuk swasta senilai tersebut jadi totalan nilai lebih bayar tahun 2017 senilai (Rp. 2.536.959.429,-) dan PT. Tri Star Mandiri memilih untuk mengembalikan/restitusi Lebih Bayar di tahun 2017.

b. PPN Tahun 2018

Dapat dilihat pada tabel 3. Penyelesaian tahap pekerjaan di mulai masa Mei 2018 dengan nilai Rp. 671.832.682,- , totalan nilai Pajak Masukan yang telah dikreditkan dari masa Januari sampai Juni senilai Rp. 428.770.458,- tanpa ada pengurangan, di posisi masa Juli 2017 Pajak Masukan bertambah Rp. 182.322.378,- tapi telah di terbitkan Faktr Pajak Keluaran karna tahap pekerjaan selesai dengan nilai cair Rp. 14.212.915 dan Pajak Keluaran bendaharawan nilai Rp. 874.253.244,- akan tetapi nilai pajak keluaran yang tidak ditanggung lebih kecil dari pajak masukan jadi status masih lebih bayar dan meningkat dari masa ke masa, begitu pula dengan masa November 2018 Pajak Masukan masih lebih besar dari Pajak Keluaran.

Pajak Masukan yang dikreditkan dari masa Januari sampai Desember 2018 sebesar Rp. 2.800.279.412 sedangkan Pajak Keluaran yang ditanggung oleh PT. Tri Star Mandiri hanya sebesar Rp. 75.212.915,- jadi nilai Lebih Bayar PT. Tri Star Mandiri sebesar (Rp. 2.725.066.498,-) yang di pungut oleh bendarawan pemerintah senilai Rp. 9.706.471.544,--.

Lebih Bayar di tahun 2018 ini PT. Tri Star Mandiri tidak memilih untuk di kembalikan/restitusikan langsung, akan tetapi memilih untuk mengkompensasikan ke masa pajak berikutnya yaitu Januari 2019.

c. Tahun 2019

Volume 1 Issue 1 (2020)

Economics and Digital Business Review

ISSN: 2774-2563 (Online) 
Surianto $^{\varpi_{1}}$, Firda Mawarni². A, Sumarni $\mathbf{S}^{3}$.

Analisis Proses Restitusi Pajak Pertambahan Nilai pada Perusahaan Jasa Konstruksi

DOI : https://doi.org/10.37531/ecotal.v1i1.5

Di tahun 2019 ini,dapat dilihat pada tabel 4. PT. Tri Star Mandiri memiliki saldo awal Lebih Bayar kompensasi dari masa Desember 2018 yang di kompensasikan ke masa Januari 2019 senilai (Rp. 2.725.066.498,-) itu sebagai penambah pajak masukan Januari 2019 yang dimana Pajak Masukan yang di kreditkan pada masa Januari senilai Rp. 268.167.859,- jadi totalan lebih bayar untuk masa Januari 2019 sebesar Rp. 2.993.234.357,- terus dikompensasikan ke masa pajak berikutnya. Seperti yang terurai pada tabel 4. Dimana pajak masukan pada tahun 2019 ini sangat menurun hanya mencapai Rp. 627.991.167,- sangat jauh perbandingan antara tahun sebelumnya, karna pada tahun 2019 PT. Tri Star Mandiri tidak mendapatkan tender sama sekali karena ada beberapa faktor antaranya PT. Tri Star Mandiri mendapatkan sanksi atau diblacklist untuk mengikuti tender di tahun 2019, akan tetapi masih ada beberapa tahapan proyek 2017 dan 2018 yang belum rampung dilanjutkan pada tahun 2019 maka dari itu PT. Tri Star Mandiri masih memiliki beberapa proyek pekerjaan yang berjalan, itu salah satu pertimbangan tidak diajukannya pengembalian/restitusi pada tahun 2018. Seperti yang ada pada tabel 4. Pajak masukan yang dikreditkan hanya senilai Rp. 627.991.167,- Pajak Keluaran yang tidak di tanggung sendiri senilai Rp. 9.113.250,- dan Pajak Keluaran yang ditanggang bendaharawan senilai Rp. 2.298.723.008,-. Jadi Pajak Masukan kompensasi dari masa pajak Desember 2018 dijumlahkan dengan Pajak Masukan Tahun 2019 yaitu Rp. 2.725.066.498,- + Rp. 627.991.167 = Rp. 3.353.057.605,- (total nilai Pajak Masukan Tahun 2019). Akan tetapi di masa Oktober dan November membuka Faktur Pajak Swasta menjadi pengurang Lebih Bayar yaitu (Rp. 3.353.057.605, - Rp. 9.113.250,- = Rp. 3.343.944.415,-). Hasil penguran itulah yang menjadi nilai Lebih Bayar tahun 2019 PT. Tri Star Mandiri, dan memilih untuk dikembalikan/restitusi pada SPT PPN Masa Desember 2019.

\section{Restitusi}

Restitusi PPN pada PT Tri Star Mandiri dilakukan hampir setiap tahunnya. Hal yang menyebabkan terjadinya restitusi adalah besarnya nilai Pajak Masukan dibanding Pajak Keluaran, dan nilai yangakan direstitusi adalah selisih dari nilai yang dikompensasikan ke masa pajak berikutnya, hal ini terjadi karena aktivitas Proyek pekerjaan bendaharawan pemerintahan yang dimana bendaharawanlah yang mempungut pajak atas pekerjaan. Setelah PT. Tri Star Mandiri telah melakukan pelaporan SPT PPN setiap masa dengan lengkap dan benar hingga masa Desember dengan status lebih bayar maka ada dua pilihan yaitu dikompensasikan atau dikembalikan/restitusi ke tahun berikutnya, jika dalam pengisian SPT Masa dengan memberi 
Surianto $^{\varpi_{1}}$, Firda Mawarni². A, Sumarni $\mathbf{S}^{3}$.

Analisis Proses Restitusi Pajak Pertambahan Nilai pada Perusahaan Jasa Konstruksi

DOI : $\underline{\text { https://doi.org/10.37531/ecotal.v1i1.5 }}$

tanda silang pada kolom dikembalikan (restitusi) maka secara tidak langsung PT. Tri Star Mandiri telah mengajukan permohonan restitusi dan DJP melakukan pengecekan, kemudian terbitlah Surat Keputusan Pengembalian Pendahuluan Kelebihan Pajak (SKPPKP) dalam hal Jumlah kredit pajak jauh lebih besar dari jumlah pajak yang terutang atau PKP melakukan pembayaran pajak yang semestinya tidak terutang. Jika terdapat pajak terutang yang dipungut oleh Pemungut PPN, maka jumlah pajak terutang adalah jumlah pajak keluaran yang dikurangi pajak masukan atau pajak yang dipungut oleh pemungut PPN tersebut. Setelah itu Penerbitan SP3 dan Pemberitahuan atau panggilan untuk PT. Tri Star Mandiri alur secara umum dapat dilihat pada 2. Hal 29. PT. Tri Star Mandiri akan dimintai dokumen yang terkait dalam SPT masa PPN sehingga terjadinya lebih bayar dengan nilai yang diajukan, beberapa di antaranya :

a) Faktur Pajak Masukan lengkap dengan pendukung kuat

b) Faktur Pajak Keluar lengkap dengan berkas pekerjaan proyek seperti SP2D, SPM, kwitansi, bukti bayar pajak

c) Kontrak Pekerjaan serta RAB Pekerjaan

d) Rekening Koran

a. Restitusi pada tahun 2017

PT. Tri Star Mandiri mengajukan permohonan Restitusi untuk tahun 2017 pada September 2018 dengan nilai lebih bayar (Rp. 2.536.959.429,-) lalu mengikuti semua prosedur yang telah ditetapkan ada beberapa kendala yang dihadapi PT. Tri Star Mandiri di antara :

1) Ada faktur pajak masukan yang tidak dapat dihitung sebagai pengeluaran pekerjaan proyek

2) Adanya faktur pajak masukan yang tidak lengkap dengan bukti pendukung

3) Lawan transaksi pajak masukan membatalkan faktur pajak tersebut

4) Adanya pencairan dana jumlah besar masuk di dalam rek. PT. Tri Star Mandiri, tetapi bukan milik proyek pekerjaan PT. Tri Star Mandiri

5) Adanya pembayaran pajak pph atas proyek pekerjaan yang tidak masuk dalam record pembayaran PT. Tri Star Mandiri

Tetapi kendala tersebut ada beberapa yang dapat diatasi dengan cara : 
Surianto $^{\varpi_{1}}$, Firda Mawarni². A, Sumarni $\mathbf{S}^{3}$.

Analisis Proses Restitusi Pajak Pertambahan Nilai pada Perusahaan Jasa Konstruksi

DOI : https://doi.org/10.37531/ecotal.v1i1.5

1) Menerima keputusan

2) Menghubungi langsung pihak lawan transaksi yang terkait

3) Mencari bukti dokumen uang masuk

4) Melakukan PBK(Pemindah bukuan) Jika memiliki bukti bayar akan tetapi salah pada jenis kode pembyaran.

Jadi dengan beberpa kendala di atas nilai yang di ajukan tidak serta merta akan cair $100 \%$, ada kenetuan DJP menyimpan kas negara untuk pengeluaran restitusi. Dari hasil yang telah di ajukan hanya Rp. 2.460.959.429,- yang di sahkan untuk dikembalikan.

b. Restitusi tahun 2018 dan 2019

PT. Tri Star Mandiri mengajukan permohonan restitusi di tahun 2019 pada bulan Januari 2020 dengan nilai lebih bayar (Rp. 3.343.944.414,00) lalu PT. Tri Star Mandiri mendapat surat panggilan dari pihak DJP terkait pembahasan Restitusi, setalah itu di terbitkan BAPK (Berita Acara Pemberian Keterangan) dan peminjaman dokumen sebagai bukti pendukung yang sah. Ada beberapa kendala yang dihadapi oleh PT. Tri Star Mandiri untuk 2019 di antara :

1) Adanya pembelian asset yang tidak memiliki bukti faktur pajak tetapi sudah ter-kreditkan

2) Adanya Rekening KMK/Pinjaman yang memiliki transaksi yang cukup besar

3) Adanya pembayaran pajak PPN atas proyek pekerjaan yang tidak masuk dalam record pembayaran PT. Tri Star Mandiri

4) Adanya record-an. PT. Tri Star Mandiri yang proyek pekerjaan di suatu daerah dan tetap tidak ada dalam omset dan tidak ada atau kata lain tidak melaporankan omset

Tetapi kendala tersebut ada beberapa yang dapat di atasi yaitu :

1) Dicarikan bukti pendukung lain terkait pembelian asset yang akurat

2)Memberikan keterangan yang akurat mengenai arus transaksi terhadap rekening pinjaman/KMK

3) Dilakukannya pemindahbukuan 
Surianto $^{\varpi_{1}}$, Firda Mawarni². A, Sumarni $\mathbf{S}^{3}$.

Analisis Proses Restitusi Pajak Pertambahan Nilai pada Perusahaan Jasa Konstruksi

DOI : https://doi.org/10.37531/ecotal.v1i1.5

4) Menerima denda yang telah ditentukan atas tidak menerbitkan faktur pajak untuk omset yang tidak di laporkan tersebut yaitu $2 \%$ dari nilai Bruto

a) Akan tetapi untuk tahun 2019 PT. Tri Star Mandiri masih menjalani tahap proses pemeriksaan Jadi adanya kendala di atas dapat dikalkulasikan beberapa potongan antara lain omset/pekrjaan yang tidak dilaporkan dengan nilai Bruto Rp 5.596.510.394,- x 2\% (denda) = Rp. 111.930.208 serta potongan potongan pajak yang masih tertunggak lainya, sambal menunggu hasil akhir dan diterbikan SPHP.

\section{Kesimpulan}

Restitusi Lebih Bayar SPT Masa PPN tidak 100\% akan dikembalikan karna adanya ketentuan dari DJP. Untuk Tahun 2017 telah diselesaikan dan telah dikembalikan oleh negara senilai Rp. 2.460.959.429,- dan untuk Tahun 2019 yang digabung Tahun 2018 masih dalam tahap pemeriksaan. Dalam proses restitusi PPN yang diajukan oleh PT Tri Star Mandiri, terdapat faktor pendukung yang menyebabkan keseluruhan proses selesai lebih cepat yaitu kerjasama antar kedua belah pihak yang ditunjukkan dengan sikap kooperatif. Faktor penghambat restitusi PPN PT Tri Star Mandiri terletak pada lawan transaksi bendaharawan yang kurangnya perhatian terhadap kelengkapan berkas penyelesaian proyek yang berkaitan pajak yang telah dipungut, dan terkadang bukti pembayaran pajak yang telah dipungut sering kali memiliki kesalahan pada kode pembayaran ataupun data yang seharusnya terisi. Maka dari itu PT. Tri Star Mandiri yang harus melakukan pemindahbukuan (PBK).

\section{References :}

Ardayani, Putu Vio Narakusuma \& I Ketut Jati. Pengaruh Tax Amnesty dan Kondisi Keuangan pada Tingkat Kepatuhan Wajib Pajak Orang Pribadi. DOI: 10.24843/EJA.2018.v25.i03.p19.

Budiadnyanyi, Ni Putu. Kepemilikan Manajerial sebagai Pemoderasi Pengaruh Capital Intensity Pada Agresivitas Pajak DOI: 10.24843/EJA.2020.v30.i09.p06.

Darmayanti, Novi. (2012). Analisis perhitungan Pajak Pertambahan Nilai(PPN) Pada CV. Sarana Teknik Kontrol Surabaya.Universitas Islam Darul Ulum Lamongan.

Dimas, Yohanes C. (2015). Analisis Prosedur Restitusi dan kompensasi dalam Penyetoran Pajak Penghasilan Orang Pribadi di Kantor Pelayanan Pajak Pratama Surakarta.Universitas Sebelas Maret.Surakarta.

Hapizar Triansyah \& Hapizar Triansyah. Analisis Faktor-faktor yang Mempengaruhi Wajib Pajak dalam Pengurusan Restitusi Pajak pada Kantor Pelayanan Pajak Pratama Bengkulu. Ekombis Review: Jurnal Ilmiah Ekonomi dan Bisnis, Vol 2, No 2 (2014). 
Surianto $^{\varpi_{1}}$, Firda Mawarni². A, Sumarni $\mathbf{S}^{3}$.

Analisis Proses Restitusi Pajak Pertambahan Nilai pada Perusahaan Jasa Konstruksi

DOI : https://doi.org/10.37531/ecotal.v1i1.5

Jusmani \& Rudi Qurniawan. Pengaruh Restitusi Pajak Pertambahan Nilai Terhadap Penerimaan Pajak Pertambahan Nilai Pada Kantor Pelayanan Pajak Pratama Palembang Ilir Barat. DOI: 10.33197/jabe.vol4.iss2.2018.181.

Kadek Katon Pranata \& Ni Luh Supadmi. Pengaruh Penerapan E-Filing pada Kepatuhan Wajib Pajak Badan dengan Biaya Kepatuhan Pajak sebagai Variabel Moderasi. Pengaruh Penerapan E-Filing pada Kepatuhan Wajib Pajak Badan dengan Biaya Kepatuhan Pajak sebagai Variabel Moderasi.

Karina, Tirayoh. (2016). Analisis Restitusi Pajak Pertambahan Nilai pada Kantor Pelayanan Pajak Pratama Palembang Ilir Barat.STIE MDP.

Kusuma, I Gusti Putu Aditya \& Agus Fredy Maradona. Peran Intelijen Perpajakan dalam Meningkatkan Penerimaan Pajak. DOI: 10.24843/EJA.2020.v30.i08.p05.

Komang Meli Dhanayanti \& Ketut Alit Suardana. Pengaruh Persepsi Wajib Pajak mengenai Penggelapan Pajak dan Keadilan Sistem Perpajakan pada Kepatuhan Pajak. DOI: 10.24843/EJA.2017.v20.i02.p23.

Lestari, Ghiki. (2013). Analisis Proses Restitusi Pajak Pertambahan Nilai PT ABC.Universitas Indonesia, Depok.

Mangundap, Purnama V. (2016). Analisis Prosedur Restitusi Kelebihan Pembarayan Pajak Pertambahan Nilai (PPN) Pada Kantor Pelayanan Pajak Pratama Manado. Accounting Department Sam Ratulangi University Manado.

Mardiasmo, (2011). Antisipasi Restitusi Pajak Pertambahan Nilai Atas Kegiatan

Muhammad Faris Naufal \& Putu Ery Setiawan. Pengaruh Sosialisasi Perpajakan, Pemahaman Prosedur Perpajakan, Umur, Jenis Pekerjaan Terhadap Kepatuhan Wajib Pajak Orang Pribadi. DOI: 10.24843/EJA.2018.v25.i01.p10.

Ni Kadek Metri Tresnalyani \& I Ketut Jati. Pengaruh Kualitas Pelayanan, Pengetahuan Perpajakkan dan Biaya Kepatuhan pada Kepatuhan Wajib Pajak Kendaraan Bermotor. DOI: 10.24843/EJA.2018.v24.i01.p22.

Octavia,Sarah. (2015). Analisis Proses Restitusi Pajak Pertambahan Nilai (PPN) di Indonesia. Universitas Barawijaya.

Pemerintah Republik Indonesia. (2013). Undang-Undang Pajak Lengkap. Mitra Wacana Media,Jakarta.

Sa'adah, Nabitatus. Kebijakan Pengampunan Pajak (Tax Amnesty) Berdasarkan Keadilan yang Mendukung Iklim Investasi Indonesia. DOI: 10.14710/mmh.46.2.2017.182-189.

Sarah Octavia dkk. Analisis Proses Restitusi Pajak Pertambahan Nilai (PPN) di Indonesia (Studi Pada PT. XYZ). DOI: 10.1803/ecotal.v1i1.5.

Suma, I Wayan. Dampak Pemilihan Rekanan Pengusaha Kena Pajak Terhadap Realisasi Penerimaan Restitusi Pajak Pertambahan Nilai pada PT. Pembangunan Perumahan (Persero ), Tbk Balikpapan Tahun 2011. Ekonomia, Vol 1, No 1 (2012). 